\title{
Red Light for the Sand Lizard in Britain
}

\author{
By K. Corbett
}

The sand lizard in Britain is well on the way to extinction, thanks to the destruction of its favoured habitats - sand dunes and dry heath. The author, who has been engaged in full-time research on the surviving populations, has started breeding sand lizards in captivity, using animals taken from sites that are being destroyed, and hopes to reintroduce them in protected areas.

$\mathbf{T}$

HE last Ice Age left the British Isles with a very sparse herpetofauna: six amphibians and six reptiles; and only England has them all. They are not protected in any way, nor do they arouse the interest that birds, flowers and insects do, so it is not surprising that the general decline in our wildlife is outstandingly evident in this neglected group. In fact, the comparative decline per number of species is not exceeded by any other group of animals in this country. However, there are now signs of an increasing interest, if not conscience, in the fate of these animals; let us hope that it is not too late.

The crested newt, frog and slow-worm are fast disappearing from southeast England, and the natterjack toad has all but vanished in the south. Of even more immediate concern is the fate of the smooth snake and the sand lizard, which, at the present rate of habitat destruction, can have little more than a decade before they reach the point of no return on the path to extinction. These last two are of particular interest for a specific preypredator relationship, and also for their discrete habitat restriction, which is presumably in harmony with an insular climate on the edge of their geographical range. Even if we ignore their more obvious aesthetic value, their latent scientific value enhances their status, and it is regrettable that no research has been directed towards any aspect of them. Such work would have provided the basis for their conservation.

Although on the north-western extreme of their geographic range, their decline is due entirely to man's intervention; there is no suggestion that it is caused by any natural factors. The coastal dune habitat has been destroyed as a result of seaside resort urbanisation, and the lowland heath areas have been rapidly degraded thanks to a combination of afforestation, agriculture, building and extreme recreational pressures. Ironically, heathlands controlled by the military have now become refuges for various species, despite the accompanying disturbance.

Until recently the sand lizard Lacerta agilis was locally common on coastal dunes from Dorset to Kent and Denbigh to Lancashire, and also on lowland dry heath in Dorset, Hampshire, Surrey and Kent. Today, apart from the rapidly decreasing habitat in east Dorset and south-west Hampshire, only two remnant areas exist, one in Lancashire and one in Surrey. Until April this year there were two such areas in Surrey, but the larger one has now been destroyed by the Hambledon council. 
The realisation of the rapid disappearance of the sand lizard since the late 1950s prompted a project aimed at its conservation. As a result of a detailed survey of its past and present distribution, and an ecological study of colonies in Surrey and Dorset, it is now possible to evaluate the requirements for permanent breeding colonies. In the wild these requirements are rarely found all together in sites larger than one acre, but in such areas the lizard population may exceed 150 per acre. The sand lizard is well able to survive in a variety of environments, but it seems that it is rarely able to breed outside these colony areas. It is the destruction of these colony sites that results in its rapid decrease and eventual disappearance; the unnatural fragmentation of heath prevents the natural recolonisation of adjacent areas as they reach breeding site status.

The fact that sites meeting these requirements are invariably small, and the permanent adult residents have shared territories of less than 100 square yards, has led me to the concept of conservation via breeding colony preservation. Land development is virtually irreversible, and, outside a few National Trust properties and nature reserves, it is unrealistic to expect any halt to the progressive development of heathland. It is therefore essential to protect the breeding colonies that not only replenish themselves but normally provide an excess of animals, which can either be allowed to repopulate surrounding land naturally or be culled for reintroduction purposes. I am now rescuing sand lizards from doomed habitats and breeding them in large outdoor vivaria in order to provide stocks for planned reintroductions to various sites. In this way I hope to repopulate five areas in Surrey and two in Sussex. This, combined with the protection of existing colonies (including the formation of four specific sand lizard reserves in Dorset) and the recognition in future of herpetological interests on bird reserves, it is hoped will ensure the survival of the sand lizard in Britain.

\section{Chillingham Wild Cattle}

THE Chillingham Wild Cattle Association reports that the herd now numbers
$36,(38$ last year), with 12 bulls and 24 cows. A young bull, abandoned by its
mother at birth in July 1967 , is being kept with an Aberdeen Angus heifer
'so that the bull may be proved in furtherance of the scheme to safeguard the
future of the wild cattle'. It is good news that thought is being taken for the
starting of another herd; the foot and mouth threat two years ago showed the
vulnerability of this single herd of wild white cattle.

\section{Dugongs in Australia}

TN March this year Queensland banned all hunting of dugongs; in April 1 hunting was banned also in all waters of the Northern Territory except for some areas in the vicinity of Aboriginal settlements and missions. In Western Australia the dugong is already fully protected, and this means that it is now protected in all Australian waters where it occurs (Brisbane northwards and round the north possibly down to Perth). But Australia is the only part of its range where the status of this Red Book species is reasonably satisfactory. 